DOI: https://doi.org/10.32836/2521-666X/2019-65-21

УДК 338.58:65.014

Яроміч С.A.

кандидат економічних наук, професор кафедри менеджменту організацій, Одеський регіональний інститут державного управління Національної академії державного управління при Президентові України

\title{
Бекетова О.А.
}

кандидат технічних наук, доцент кафедри економічної кібернетики та інформаційних технологій, Одеський національний політехнічний університет Антоненкова Н.А. магістрант, Одеський регіональний інститут державного управління Національної академії державного управління при Президентові України

\section{Yaromich Svitlana, Antonenkova Nataliya}

Odessa Regional Institute for Public Administration of the National Academy for Public Administration office of the President of Ukraine

\section{Beketova Olena}

Odessa National Polytechnic University

\section{ОСОБЛИВОСТІ МАРКЕТИНГУ ПЕРСОНАЛУ ТРАНСПОРТНО-ЕКСПЕДИТОРСЬКИХ ПІДПРИЕМСТВ УКРАЇНИ}

\author{
FEATURES OF MARKETING TO PERSONNEL \\ OF TRANSPORT AND FORWARDING FACILITIES OF UKRAINE
}

\begin{abstract}
У статті досліджено сутність маркетингу персоналу, а також визначено основні проблеми та напрями його використання під час управління персоналом підприємств Украӥни, що надають транспортно-експедиторські послуги. Надано визначення маркетингу персоналу як виду управлінської діяльності, спрямованого на довготривале забезпечення організачії людськими ресурсами. Визначено семантику поняття «маркетинг персоналу». Розроблено комплексну систему формування внутрішнього ринку прачі на засадах сучасного маркетингу, яка забезпечує його збалансованість, гармонізацію економічних інтересів суб 'єктів сочіально-трудових відносин. Визначено, які принципи управління персоналом можуть бути застосовано й для маркетингу персоналу. Проаналізовано склад $і$ зміст вимог до персоналу, які висуваються працедавиями.

Ключові слова: маркетинг персоналу, персонал-маркетинг, управлінська діяльність, потреба в персоналі, людські ресурси, принципи управління персоналом, транспортно-експедиторські підприємства.

В статье исследована сущность маркетинга персонала, а также определены направления его использования при управлении персоналом предприятий Украины, предоставляющих транспортно-экспедиторские
\end{abstract}


услуги. Дано определение маркетинга персонала как вида управленческой деятельности, направленного на длительное обеспечение организации человеческими ресурсами. Определена семантика понятия «маркетинг персонала». Разработана комплексная система формирования внутреннего рынка труда на принципах маркетинга, которая обеспечивает его сбалансированность, гармонизацию экономических интересов субъектов сочиально-трудовых отношений. Определено, какие принципы управления персоналом могут быть применимы и для маркетинга персонала. Проанализированы состав и содержание требований к персоналу, предъявляемых работодателями.

Ключевые слова: маркетинг персонала, персонал-маркетинг, управленческая деятельность, потребность в персонале, человеческие ресурсы, приниипы управления персоналом, транспортно-экспедиторские предприятия.

This article explores the essence of Human Research Marketing as a philosophy and a strategy for managing human resources, as a marketing of labor services, defines the main directions of its use in the personnel management of forwarding enterprises in Ukraine. It is established that in the labor market the objects of marketing are: labor (labor services) and jobs. A comprehensive system for the formation of the internal labor market on the principles of marketing has been developed, which ensures the balance and harmonization of the economic interests of the subjects of social and labor relations. It has been proven that marketing staff intersects with ego-marketing and self-marketing staff. The main directions of staff marketing were formulated: determination of requirements for employees (workplace); the study of modern needs in the labor market in staff; calculation of costs for the acquisition, use and development of personnel; search for effective sources to cover staffing needs. The main stages of development of the staff marketing management system are determined. It substantiates which principles of personnel management in an enterprise can be applied to HR marketing. The composition and content of the requirements for personnel submitted by employers, in particular freight forwarding enterprises, were also analyzed. The list of necessary skills for working in a freight forwarding company is defined. First of all, employers emphasize the need for knowledge of the English language, as a rule, at a level not lower than «B2» according to international gradation. The next requirement is knowledge of international Incoterms rules. Incoterms scope covers the rights and obligations of sellers and buyers under a sales contract regarding the supply of goods. Also important are the requirements for employee communication skills, PC knowledge, attentiveness, friendliness and teamwork. Much attention is paid to how a person can effectively learn and use the «soft skill» as a certain universal set of traits and skills. The article proposes a cost structure for the personnel of the analyzed enterprises.

Keywords: personnel marketing, managerial activities, personnel requirements, human resources, personnel management principles, freight forwarding enterprises.

Постановка проблеми. За останні десятиліття методи маркетингу знайшли своє застосування в усіх сферах життєдіяльності, у тому числі й у сфері управління персоналом. Свропейські компанії вже із 70-х років XX ст. досить успішно застосовують методи класичного маркетингу у сфері управління персоналом. В Україні використання таких методів тільки починає знаходити своє широке застосування на практиці. Політика визначення витрат на робочу силу (тобто вкладення в персонал) визначає підходи до розвитку власного персоналу і залучення потрібної робочої сили, підготовки і перепідготовки кадрів до формування і реалізації соціальних програм.

Маркетинг персоналу (персонал-маркетинг) розглядається як вид управлінської діяльності, спрямований на визначення потреби в персоналі та покриття іiі. Рольф Вундерер дотримується думки, що маркетинг персоналу являє собою філософію і стратегію управління людськими ресурсами [2, с. 26]. При цьому персонал розглядається як зовнішні і внутрішні клієнти підприємства.

Аналіз останніх досліджень і публікацій. Питання персонал-маркетингу розглядалися у роботах вітчизняних і закордонних учених, зокрема М. Бєлявцева [1], Т. Глушман [3], В. Колпакова [4], О. Криворучка [5], М. Матвіїва [6] та ін.

Так, М. Бєлявцев визначає маркетинг персоналу як вид управлінської діяльності, спрямований на довгострокове забезпечення організації людськими ресурсами [1, с. 605]. T. Глушман визначає маркетинг персоналу як вид управлінського впливу, спрямованого на задоволення якісної і кількісної потреби в персоналі організації [3, с. 325]. Дані 
визначення носять оперативний характер, спрямовані на виявлення і покриття поточної потреби в персоналі. Це формулювання, на нашу думку, точніше відображає мету і значущість маркетингу персоналу для формування стратегії і тактики виживання підприємства в ринкових умовах.

Аналізуючи різні підходи до цього питання, можна відзначити, що необхідно надати більш конкретне визначення поняття маркетингу персоналу, сформулювати принципи та чинники, що впливають на його діяльність.

Мета статті полягає в уточненні сутності маркетингу персоналу на підприємствах на основі сучасних тенденцій його розвитку та формулюванні сучасних вимог до персоналу транспортно-експедиторських підприємств.

Виклад основного матеріалу. Маркетинг персоналу - це, перш за все, маркетинг трудових послуг. Для того щоб переконати покупця зробити покупку, продавці формалізують найбільш значущі для покупця формати послуги і представляють ії наочно. Це можуть бути дипломи, сертифікати, свідоцтва, атестати, рекомендації тощо. Отже, на ринку праці об'єктами маркетингу виступають персонал і робочі місця, тому маркетинг персоналу починається з визначення та забезпечення потреби у кваліфікованому й професійному персоналі на підставі досліджень ринку праці. У цьому контексті маркетингові засоби використовуються у двох видах:

- маркетинг, орієнтований на продукт, яким є послуги праці;

- маркетинг, орієнтований на задоволення потреб роботодавців.

Співбесіда - це також продаж: кандидат продає себе пошукачеві. Маркетинг персоналу дослідниками пропонується розглядати в двох сенсах. У вузькому сенсі $\epsilon$ він виступає частиною постачальницького, тому що його основне завдання полягає у забезпеченні підприємства кадрами. У широкому сенсі маркетинг виступає як активна форма соціального обміну між підприємством і ринком праці.

Слід зауважити, що маркетинг персоналу перетинається із самомаркетингом, сучасна концепція якого може розглядатися як системний підхід до самореалізації працівника, коли він в умовах конкуренції повинен визначити свій статус у суспільстві за рахунок природних здібностей, знань, умінь, навичок і активної життєвої позиції. Соціально орієнтований ринок праці створює певні умови для життя, діяльності і розвитку всіх членів суспільства, що відбувається завдяки зусиллям найбільш активних і самодостатніх осіб, які турбуються не тільки про особисте благополуччя, а й благополуччя всього суспільства. Тому аналіз сучасних концепцій маркетингу персоналу показує, що маркетинг персоналу - вид діяльності, спрямований на забезпечення підприємств людськими ресурсами. Головними напрямами маркетингу персоналу як відокремленої функції служби управління персоналом виступають:

- побудова вимог до працівників (робочого місця);

- визначення сучасної потреби на ринку у персоналі;

- розрахунок витрат на придбання, використання та розвиток персоналу;

- пошук існуючих джерел покриття потреби в персоналі.

Розглянемо детальніше семантику поняття «маркетинг персоналу» $з$ погляду дослідників (табл. 1).

Деякі принципи управління персоналом можуть бути застосовані й для маркетингу персоналу. До них можна віднести принципи:

- науковості - розроблення заходів маркетингу персоналу повинно грунтуватися на досягненнях науки в галузі менеджменту, соціології та психології;

- перспективності - під час формування стратегії маркетингу персоналу слід ураховувати перспективи розвитку підприємства;

- комплексності - під час формування заходів маркетингу персоналу необхідно враховувати зовнішні і внутрішні чинники, що впливають на їх розроблення;

- гуманізму - маркетинг персоналу грунтується на індивідуальному підході, який виражається у сприйнятті персоналу як головного потенціалу, а кожного працівника - як особистості; 
Таблиця 1

Семантика поняття «маркетинг персоналу»

\begin{tabular}{|l|l|}
\hline \multicolumn{1}{|c|}{ Автор } & \multicolumn{1}{|c|}{ Семантика поняття з погляду дослідників } \\
\hline А. Желєзнов & $\begin{array}{l}\text { Вид управлінської діяльності, спрямованої на задоволення потреб у персоналі орга- } \\
\text { нізації, одна з основних функцій якої, а також діагностика професійної придатності й } \\
\text { ротація передбачають процедуру оцінки трудової діяльності, ділових і особистих яко- } \\
\text { стей співробітників }\end{array}$ \\
\hline А. Брас & $\begin{array}{l}\text { Певна філософія ставлення до власного персоналу (як існуючого, так і майбутнього) } \\
\text { з боку підприємства. Це практична діяльність (функція) служб управління персоналом } \\
\text { підприємства з оперативного забезпечення потреб у персоналі на основі дійсної інфор- } \\
\text { мації про стан персоналу підприємства й ринку праці }\end{array}$ \\
\hline А. Кібанов & $\begin{array}{l}\text { Вид управлінської діяльності, спрямованої на довготривале забезпечення підприєм- } \\
\text { ства людськими ресурсами }\end{array}$ \\
\hline Р. Вундерер & $\begin{array}{l}\text { Філософія управління людськими ресурсами, які, орієнтуючись на життєві та трудові } \\
\text { запити працівників, відповідають інтересам підприємства }\end{array}$ \\
\hline Т. Комісарова & $\begin{array}{l}\text { Вид управлінської діяльності, спрямованої на довгострокове забезпечення організації } \\
\text { трудовими ресурсами, які утворюють стратегічний потенціал, за допомогою якого мож- } \\
\text { ливо вирішення конкретних цільових завдань }\end{array}$ \\
\hline Т. Савченко & $\begin{array}{l}\text { Вид управлінської діяльності, спрямованої на визначення та покриття потреби в персо- } \\
\text { налі в мінливому зовнішньому середовищі; планування усіх видів діяльності персона- } \\
\text { лу; вивчення чинників зовнішнього і внутрішнього ринків, які впливають на вакансію, } \\
\text { ймовірність та швидкість їі заповнення, умов схвалення кандидатури }\end{array}$ \\
\hline
\end{tabular}

- оптимальності - опрацювання всіх пропозицій і вибір раціональних варіантів щодо формування і реалізації плану маркетингу персоналу;

- оперативності - своєчасне прийняття рішень щодо усунення недоліків плану маркетингу персоналу та приведення його у відповідність до мінливих умов;

- узгодженості - передбачає взаємопов'язаність плану маркетингу персоналу з основними цілями підприємства;

- індивідуалізації роботи з персоналом передбачає врахування особистих і трудових потреб кожного співробітника, що працює на підприємстві.

Розглянемо проблеми маркетингу персоналу на прикладі підприємств, які пропонують транспортно-експедиторські послуги. В умовах постійних змін ринкових відносин важливо пристосувати систему управління персоналом для будь-яких умов та зробити іiі якомога гнучкішою. Це визначає рівень якості послуг та допомагає підприємству завоювати більшу частину ринку.

За останні 20 років ринок транспортноекспедиторських послуг України істотно розширився і перетворився на самостій- ну повноцінну індустрію, що забезпечує стабільний дохід своїм засновникам і країні у цілому, тому що більшість товарів у світі перевозяться в контейнерах. Порти «Великої Одеси» (Одеса, Південний, Чорноморськ та контейнерні термінали, розташовані в них (компанія «ТрансІнвестСервіс» (ТIC), ТОВ «Бруклін-Київ Порт» (БКП) i рибний порт) $є$ «морськими воротами» України для всіх контейнерних вантажів. Тож не дивно, що більшість транспортноекспедиторських компаній, що займаються перевезеннями, зосереджено саме в Одесі. Сьогодні їх приблизно 460. Таким чином, транспортно-експедиторські підприємства забезпечують робочими місцями щонайменше 3 тис осіб, і ще стільки ж людей зайняті в суміжних сферах.

3 огляду на те, що в Україні на даний момент не існує інституту експедиції контейнерних вантажів, цей ринок і структура підприємств почали формуватися хаотично понад 20 років тому, виробляючи свої власні правила, норми і порядок взаємин із контрагентами та працівниками підприємств. Навіть закон про транспортно-експедиторську діяльність України був прийнятий у 2004 р. 
Центральним елементом взаємодії між клієнтом та продавцем чи виробником $є$ товар або послуга транспортно-експедиторської діяльності. Товар має свою споживчу вартість, що визначає його здатність до вирішення та задоволення потреб. Таку ж вартість мають і транспортно-експедиторські послуги, яка має низку споживчих особливостей, що відображаються за допомогою інтегрального показника якості надання такого роду послуг.

Цей показник прямо впливає на конкурентоспроможність підприємства шляхом співставлення інтегрального показника із ціною споживання товару. Звертаючись до експертної оцінки чинників впливу на ефективність управління транспортно-експедиторською діяльністю, важливу роль відіграють чинники надійності вибраного транспорту, дотримання певних графіків доставки та вартість перевезення товару. Розроблення нових методологічних аспектів управління та впровадження сучасних підходів до транспортно-експедиторської діяльності зумовлено розширенням експорту транспортних послуг у зовнішньоекономічній діяльності та в транспортуванні у цілому. Таким чином, експедитори виступають як посередники між перевізником та власником товару, а також мають право приймати участь у підготовці до перевезень та несуть відповідальність за збереженість вантажу, забезпечують повний цикл транспортування від відправника до замовника або від пункту призначення до місця прибуття.

Вказані проблеми, які характерні для процесів функціонування експедиторів на сучасному ринку транспортних послуг, дають змогу визначити напрями перспективних досліджень щодо підвищення ефективності транспортного обслуговування, зокрема:

- формування нових і адаптація існуючих моделей управління процесом обслуговування вантажовласників;

- обгрунтування сукупності технологічних операцій для процесів обслуговування клієнтури експедиторських підприємств;

- розроблення інформаційних інструментів підтримки прийняття рішень під час управління процесом техніко-економічного обгрунтування (ТЕО).

У розробленні системи управління маркетингом персоналу можна виділити декілька етапів:

- планування - формування цілей управління, способів їх досягнення, а також прогнозування об'єкта управління;

- організація - процес підбору кадрів за профорієнтацією, залучення професійного персоналу, розстановка по робочих місцях, кваліфікаційна підготовка, вдосконалення системи організації праці, поліпшення умов праці та інші операції, пов’язані з організацією робочих місць;

- регулювання - кваліфікаційний рух робочої сили по підприємству, зміна чисельності персоналу, рівня заробітної плати, регулювання доплат та ін.;

- контроль - контроль чисельності персоналу, раціональності використання робочих годин, виконання кадрових наказів та ін.;

- облік - аналіз інформації про зміну складу кадрів, ведення державної і внутрішньої звітності з плинності кадрів та ін.

Витрати на персонал таких підприємств мають таку структуру:

- заробітна плата, нарахована працівникам за тарифними ставками і окладами за відпрацьований час;

- премії та винагороди, що носять регулярний чи періодичний характер;

- доплата за роботу у шкідливих умовах;

- оплата роботи у вихідні та святкові дні;

- оплата щорічних відпусток;

- оплата навчальних відпусток, наданих працівникам, які навчаються в освітніх установах;

- компенсація жінкам, які перебувають у частково оплачуваній відпустці по догляду за дітьми;

- оплата лікарняних листів.

Так само до витрат на персонал можна віднести такі витрати:

- на набір персоналу: оплата реклами вакансій у друкованих виданнях та Інтернет-сайтах;

- вартість уніформи працівників; 
- харчування окремим категоріям працівників, які працюють у шкідливих умовах;

- податки на використання найманої праці;

- охорона праці.

Спостерігаючи сьогодні за вакансіями на різних сайтах пошуку роботи, можна побачити чітку закономірність необхідних навичок для роботи в транспортно-експедиторській компанії. $€$ перелік загальних умов для будь-якої посади, а також вузькоспеціалізованих знань.

Розглянемо склад і зміст вимог до персоналу, які висуваються працедавцем (табл. 2).

У першу чергу стоїть вимога знання англійської мови, загалом від рівня не меншого за «А2» за міжнародною градацією. Для деяких посад - не нижче «В2», оскільки ця діяльність передбачає міжнародну взаємодію.

Наступним фактором є знання правил «Інкотермс». Мабуть, це найголовніші знання у цій галузі. Третє місце займають усі інші вимоги: комунікабельність, знання ПК на рівні користувача, уважність (на нашу думку, дуже важливе вміння), доброзичливість та вміння працювати в команді.

Дуже багато уваги приділяється тому, як людина може навчатися та як досконало вміє використовувати soft skills. Soft skills включають у себе хороші усні і письмові комунікаційні навички, здатність співчувати та співпереживати іншим; здатність співпрацювати і вести переговори; готовність вирішувати проблеми й навички врегулювання конфліктів. Можна говорити, що soft skills - це про здоровий глузд і емоційний інтелект. Також soft skills часто називають навичками роботи з людьми або міжособистісними навичками, тому що вміння працювати й виконувати свою роботу можна, набувши певні вузькоспеціальні знання.

Також є більша вірогідність того, що людина 3 такими навичками зможе прийняти та зрозуміти основні поняття компанії, такі як візія, цінності та місія компанії. А це, своєю чергою, дуже впливає на спроможність колективу йти до спільної мети та розбирати конфліктні ситуації з більш зрозумілою ясністю.

Варто також зазначити, що деякі посади в галузі підлягають обов'язковому ліцензуванню, наприклад керівник залізничних чи автоперевезень, юристи. Слід підкреслити, що найкращий здобувач - це кандидат, який розуміє і відображає історію компанії, відповідає корпоративній культурі і любить свою роботу.

Для більш чіткого бачення менеджменту персоналу транспортно-експедиторської галузі треба звернути увагу на типи організаційних структур цих підприємств, адже саме від цього починається 3'ясування та налагодження клімату на підприємстві та створення власного HR-бренду. Це сукупність зусиль компанії щодо взаємодії з існуючими та потенціальними співробітниками, яка робить іï привабливим місцем роботи, а також активне управління іміджем компанії в очах партнерів, потенційних співробітників та інших

Таблиця 2

\section{Склад і зміст вимог до персоналу, які висуваються працедавцем}

\begin{tabular}{|c|l|}
\hline $\begin{array}{c}\text { Група вимог } \\
\text { праці }\end{array}$ & \multicolumn{1}{|c|}{ Зміст показників, які утворюють групу вимог } \\
\hline $\begin{array}{c}\text { Особисті } \\
\text { здібності } \\
\text { працівника }\end{array}$ & $\begin{array}{l}\text { Освіта. Досвід роботи в певній сфері діяльності. Навички виконання загальних функ- } \\
\text { цій управління Здатність швидко сприймати суть справи. Здібності аналізувати про- } \\
\text { блеми і робити висновки. Здатність до рішень і готовність відстоювати свої наміри }\end{array}$ \\
\hline $\begin{array}{c}\text { Властивості } \\
\text { особи працівника }\end{array}$ & $\begin{array}{l}\text { Особові якості, необхідні для визначеного виду діяльності. Здатність до концентра- } \\
\text { ціїлиль пам'яті, уваги, Вміння якісно виконувати роботу в умовах дефіциту часу. } \\
\text { Здатність до навчання. Комунікабельність. Охайний зовнішній вигляд }\end{array}$ \\
\hline $\begin{array}{c}\text { Мотиваційні } \\
\text { установки до } \\
\text { праці }\end{array}$ & $\begin{array}{l}\text { Сфера професійних інтересів. Прагнення до саморозвитку через професійне і по- } \\
\text { садове зростання службової кар'єри. Зацікавленість у роботі по певній посаді або } \\
\text { характеру роботи. Визначеність власних професійних перспектив }\end{array}$ \\
\hline $\begin{array}{c}\text { Професійна } \\
\text { поведінка } \\
\text { працівника }\end{array}$ & $\begin{array}{l}\text { Готовність до праці. Особиста ініціатива. Навички ділового стилю спілкування. На- } \\
\text { вички командної роботи з колегами по роботі. Здатність до риторики або письмової } \\
\text { роботи }\end{array}$ \\
\hline
\end{tabular}


ключових стейкхолдерів. Управління брендом роботодавця (employer brand management) розширює сферу застосування HR-бренду в комунікації шляхом його включення в усі аспекти HR-менеджменту, які формують уявлення існуючих і потенційних співробітників.

Інакше кажучи, управління брендом роботодавця звертається до реального трудового досвіду, а не просто його поданням, тим самим підтримуючи як зовнішній рекрутмент потрібних компанії фахівців, які прагнуть до досягнення цілей організації, так і ефективне залучення співробітників у трудовий процес та їх утримання. Інструментом управління брендом роботодавця $є$ брендбук роботодавця. Він включає у себе опис місії і цілей компанії, ключових характеристик бренду роботодавця, айдентики бренду, а також зовнішню і внутрішню комунікаційні стратегії.

Внутрішній маркетинг персоналу зосереджений на передачі повідомлення споживачам бренду, а також повідомленні співробітникам компанії певних звичок і поведінки для донесення цього повідомлення до споживачів. Незважаючи на очевидну вигоду для організації в розумінні ії співробітниками своєї ролі в доставці цього повідомлення споживачам, часто ефективність внутрішнього маркетингу виявляється короткостроковою. Це відбувається в тому разі, якщо цінності, на яких базується бренд компанії для споживачів, не випробовуються самими співробітниками компанії в процесі роботи. Це розрив, який можна подолати за допомогою розвитку бренду роботодавця шляхом пошуку більш взаємовигідного трудового контракту [6, с. 54].

Як говорилося раніше, висококваліфікований персонал - це основа процвітаючої транспортно-експедиторської компанії, тому на таких великих підприємствах найчастіше проводиться постійна робота 3 підвищення професійних якостей співробітників. Так, на базі підприємства можуть бути організовані курси іноземних мов, тренінги 3 розвитку технік продажів, курси підвищення кваліфікації для фахівців.

Рівень нематеріальної мотивації персоналу в подібних підприємствах до- сить високий, і керівництву слід постійно приділяти увагу розвитку персоналу. Ринок праці формується, зростає, постійно змінюється разом із ним і пропозиція на біржі праці. Вимоги до кандидатів можуть відрізняться від функцій, які він виконував на попередньому місці роботи. Тому гнучкість, здатність швидко навчатися й адаптуватися високо цінується. На прикладі цієї галузі, особливо на території Одеси, де ринок дуже динамічний, яскраво виражені вимоги до претендента, характерні для XXI ст. Здатність швидко вчитися, перекваліфікуватися високо цінується у сегменті логістики.

Ще один важливий момент у маркетингу персоналу: яким би диверсифікованим не було підприємство, воно може створити корпоративну вартість, забезпечуючи випереджаюче управління вихованням своїх лідерів і формуванням «людського капіталу». У глобальній економіці, що базується на знаннях, нематеріальні активи, такі як людський капітал, становлять приблизно 80\% вартості організації. Перетворення нематеріальних активів на матеріальні результати представляє для більшості організацій новий спосіб мислення. Ті, кому вдається освоїти цей процес (що багато в чому залежить від організації роботи $з$ персоналом), можуть забезпечити собі значну конкурентну перевагу [5, с. 12].

Широко розповсюдженим засобом впливу на працівника, на трудові відносини, що складаються, є мотивація праці, що передбачає:

- систему винагороди, матеріального і морального заохочення;

- збагачення змісту праці, підвищення інтересу до роботи;

- розвиток персоналу, надання можливості професійно-кваліфікаційного просування, планування кар'єри;

- поліпшення соціально-психологічного клімату на підприємстві завдяки зміні стилю управління, умов наймання і роботи, заохоченню індивідуальної й групової ініціативи, творчості і саморозвитку;

- активне залучення працівників до управління трудовими процесами, участь у прибутках підприємства тощо. 
Висновки. Підводячи підсумки, можна побачити закономірність та взаємопов'язаність багатьох чинників, які впливають на розвиток транспортно-експедиторської галузі. Одним з основних таких чинників є маркетинг персоналу, який завдяки стратегічному підходу може налагодити роботу всього підприємства. Саме завдяки правильному підходу до підбору кадрів можна грунтовно підійти до питання взаємовідносин в організації, а це, своєю чергою, стає значним фундаментом для довгострокового зростання компанії на ринку України, а згодом і на світовому ринку.

Використовуючи сучасні методи підбору персоналу, його мотивації та стратегічного підходу до колективу, можна створити дійсно сильну компанію, в якій буде сприятливий емоційний клімат.

\section{Список літератури:}

1. Белявцев M.І., Калиниченко М.П. Маркетинг персоналу промислового підприємства. Формування ринкової економіки. 2013. Вип. 30. С. 601-620.

2. Вундерер Р. Маркетинг персонала - искусство создания благоприятных условий труда. Проблемы теории и практики управления. 1992. № 5. С. 111-115.

3. Глушман Т.М. Маркетинг персоналу як інструмент реалізації кадрової політики підприємства. Глобальні та національні проблеми економіки. 2016. Вип. 14. С. 322-326.

4. Колпаков В.М. Маркетинг персоналу : навчальний посібник. Київ : МАУП. 2006. 408 с.

5. Криворучко O.М., Гладка О.I. Встановлення сутності поняття «маркетинг персоналу». Економіка транспортного комплексу. 2012. Вип. 19. С. 5-16.

6. Матвіїв М. Персонал у комплексі маркетингу на ринку праці. Галицький економічний вісник. 2010. № 3(28). С. 50-56.

7. Савченко В.А. Управління розвитком персоналу : навчальний посібник. Київ : КНЕУ. 2002. $351 \mathrm{c}$.

8. Сардак О.В. Види персонал-маркетингу підприємств. Вісник соиіально-економічних досліджень. 2012. Вип. 2. С. 171-175.

\section{References:}

1. Beljavcev M.I., Kalinichenko M.P. (2013) Marketing personalu promislovogo pidpriemstva. [Marketing of personnel of industrial enterprise]. Formuvannja rinkovoyi ekonomiki : zb. nauk. pr. DVNZ «Kyiv. nac. ekon. un-t im. Vadima Get'mana». - Kyiv : KNEU. Vip. 30. pp. 601-620. (in Ukrainian).

2. Vunderer R. (1992) Marketing personala - iskusstvo sozdanija blagoprijatnyh uslovij truda. [Personnel marketing is the art of creating favorable working conditions]. Problemy teorii i praktiki upravlenija. № 5. pp. 111-115. (in Russian).

3. Glushman T.M. (2016) Marketing personalu jak instrument realizaciyi kadrovoyi politiki pidpriemstva. [Personnel marketing as a tool for implementing the personnel policy of the enterprise]. Global'ni ta nacional'ni problemi ekonomiki. Vip. 14. pp. 322-326. (in Ukrainian).

4. Kolpakov V.M. (2006) Marketing personalu: navch. posib. dlja stud. sered. i vishh. navch. zakl. [Staff Marketing: Teach tool. for students. among. and higher. teach.]. Kyiv : MAUP. 408 p. (in Ukrainian).

5. Krivoruchko O.M., Gladka O.I. (2012) Vstanovlennja sutnosti ponjattja «marketing personalu». [Establishing the essence of the concept of «personnel marketing»]. Ekonomika transportnogo kompleksu, Vip. 19. pp. 5-16. (in Ukrainian).

6. Matviyiv M. (2010) Personal v kompleksi marketingu na rinku praci. [Staff in the labor market marketing complex]. Galic 'kij ekonomichnij visnik. №3(28). pp. 50-56. (in Ukrainian).

7. Savchenko V.A. (2002) Upravlinnja rozvitkom personalu: navch. posibn. [Human Resource Management: Educ. Manual]. Kyiv : KNEU. 351 p. (in Ukrainian).

8. Sardak O.V. (2012) Vidi personal-marketingu pidpriemstv. [Types of personnel marketing enterprises]. Visnik social'no-ekonomichnih doslidzhen', Vip. 2. Pp. 171-175. (in Ukrainian). 